\title{
The market for paintings in the Venetian Republic from Renaissance to Rococò
}

\author{
Federico Etro • Laura Pagani
}

Received: 9 March 2011/Accepted: 22 October 2012

(C) Springer Science+Business Media New York 2012

\begin{abstract}
We study the art market in the Venetian Republic from 1550 to 1750 analyzing the determinants of the prices (adjusted for the cost of living measured by the price of wheat) of figurative paintings. Reputation of the painters, size of the paintings and other quantifiable factors affect prices as expected. Other relevant factors include the placement of the paintings (on altars, ceilings or walls), whose impact reflects differences in demand elasticities. We find evidence of the law of one price confirming price equalization between high and low demand geographical destinations and between different subjects. Finally, in a Schumpeterian perspective, we relate the temporal trend of the price of a representative painting with waves of artistic innovations, whose peacks were in the 1500s and in the 1700 s with a dark Baroque age in the intermediate century.
\end{abstract}

Keywords Art market $\cdot$ Endogenous market structures $\cdot$ Hedonic pricing analysis

JEL Classification Z11 $\cdot$ N0 $\cdot$ D4

\section{Introduction}

The objective of this work is to analyze the market for figurative paintings traded in the Venetian Republic between the second half of the XVI century and the first half of the XVIII century, emphasizing the economic determinants of the real compensations for these artworks, that is their prices adjusted for the cost of living.

\author{
F. Etro \\ University of Venice Ca' Foscari, Venice, Italy \\ e-mail: federico.etro@unive.it \\ L. Pagani ( $\square$ ) \\ University of Milan Bicocca, Milan, Italy \\ e-mail: laura.pagani@unimib.it
}


This allows one to test a number of economic predictions and to obtain the trend of the real compensation for a representative painting produced in Venice over two centuries, which provides interesting insights on the evolution of the art market.

The period under analysis starts at the end of Renaissance, during the so-called Mannerist age (approximately 1550-1600), continues during the Baroque age (approximately most of the 1600s) and includes what is usually called the Rococò age (up to the middle of the 1700s). In these centuries, the pricing of an art object was perceived as highly subjective and largely dependent on taste, wealth and prestige of the buyers, with little regard for factors affecting demand and supply. Honour and prestige were claimed to be the drivers of social and economic activities rather than profit-seeking behavior. In spite of this, we know that the market for paintings reached a wide dimension, developed well organized institutions, introduced specific contractual solutions, employed a high number of artists in competition with each other, and served a wide audience of commissioners. As a consequence, we expect that the price of paintings should be closely related to the general conditions of demand and supply, and we test this hypothesis on a dataset based on the records collected by Sohm (2010). This latter contains information on prices in silver ducats and other features of paintings traded in the Venetian Republic.

We adjust nominal prices for the cost of living using data on the price of wheat, as calculated by Malanima (2002). Wheat was an essential good for most of the population and its price variations were likely to be reflected on those of many other goods. Using this procedure we translate nominal prices in real terms reflecting the changes in the cost of living during two centuries and thus we base our econometric investigation on a more reliable measure of the values of the artworks, that is on their ducats' purchasing power.

The equilibrium prices of artworks can be interpreted in terms of hedonic prices reflecting the expected aesthetic value of the paintings. Rosen (1974) has suggested a two-step procedure to estimate demand and supply of particular hedonic features. ${ }^{1}$ Our interest, however, is not about identifying demand and supply for hedonic features, but about correlations of demand and supply variables with the equilibrium prices emerging in the market; therefore, we regress the log of the real compensations on a number of control variables using a standard OLS estimator-see Anderson (1974) and Chanel et al. (1996) for early empirical applications of this methodology in the economics of art.

Our results show that the painters' real compensation depended on their reputation, which we capture by artists' fixed effects, and, beyond this, that a number of supply and demand factors affected the equilibrium compensations as expected. A positive and concave relation between prices and size of paintings reflects economies of scale in the production of artworks. Other relevant factors include the placement of the paintings (on the altar, on the ceiling or on the walls), whose impact reflects differences in demand elasticities, or in a religious or secular building. We support the idea that patrons and artists adopted a typical solution to

\footnotetext{
1 Subsequent contributions included Brown and Rosen (1982), Bartik (1987) and Nerlove (1995) on econometric theory and Witte et al. (1979), Palmquist (1984) and Bajari and Benkard (2005) on empirical applications.
} 
the moral hazard problem: prices were made conditional on measurable features of the paintings which were positively correlated with quality, the main one being the number of human figures. ${ }^{2}$

We also evaluate whether the law of one price did hold checking for price equalization between paintings sold in different points of sale (geographical destinations) and paintings of different figurative subjects, that is sacred versus mythological, historical and battles. The mobility of painters was high, therefore we should expect that differentials in real compensations between high-demand and low-demand towns or between different genres should be arbitraged away. Indeed, this is what we find: Venice or foreign cities were not paying more their painters compared to the countryside (as often thought because of higher demand), but they were just selecting the best quality painters for more ambitious commissions. ${ }^{3}$

Analogously, we find price equalization between similar paintings of different subject. We also check for measures of the rate of production of the painters without clear-cut results.

Most importantly, we check how the price of a representative painting (with given features by a given painter) changed over time. The two centuries analyzed here were characterized by the golden age associated with the innovative masters of late Renaissance and Mannerism (Titian, Veronese and Tintoretto), by the dark age of the Baroque period in which Venetian painters contributed marginally to the evolution of art history, and by the renaissance of the Venetian Rococò period with innovators that influenced the western art history in a radical way (Tiepolo, Ricci, Canaletto). Controlling for paintings' and painters' features, we find evidence of high and declining prices in the late XVI century, low prices during two-thirds of the XVII century and increasing prices in the last part of the same century and during the first half of the XVIII century. This is consistent with the hypothesis that the compensation of the artistic activity may have contributed to determine artistic innovations, promoting the two prominent periods of Venetian art and providing a possible market-based explanation for the decline of artistic achievements during the intermediate phase. Not only was art a full-fledged market, but the market may have driven art as well, an hypothesis that awaits for further investigation.

Our analysis is related to a wide literature in cultural economics investigating data on secondary sales in modern art auctions. Starting with Anderson (1974) and Baumol (1986), this literature has been aimed at estimating the return from the investment in art (see among others Frey and Pommerehne 1989; Buelens and Ginsburgh 1993; Mei and Moses 2002) or at pointing out some determinants of art values through hedonic regressions (Chanel et al. 1996; Dorchy and Ginsburgh 1993; Galenson and Weinberg 2000; Nahm 2010). The first work to consider data on primary sales has been the one by Rengers and Velthuis (2002), whose focus was on contemporary Dutch artists.

\footnotetext{
${ }^{2}$ See Holmstrom (1979). One of the first works to point out (different) contractual solutions to trade problems emerging in a medieval environment is by Greif et al. (1994).

3 This selection effect is reminiscent of the one pointed out by Melitz (2003) in the literature on trade with heterogenous firms: in particular, only the most productive painters could sell their works abroad.
} 
A smaller literature has been focused on historical art markets. For instance, De Marchi (1995) and Montias (2002) have emphasized the importance of economic incentives in shaping the Dutch golden age of Baroque paintings, ${ }^{4}$ while Cecchini (2000) and Fantoni et al. (2003) provide an economic history background on the Venetian market. $^{5}$

Gérin-Jean (2003) has analyzed the prices of heterogeneous artworks (statues, decorative objects and also paintings) from inventories (and not original contracts) of the Medici period, but the procedure used for converting prices into a unique currency and the adjustment for inflation, using an index computed for Southern England, appear inaccurate. O'Malley (2005) and Spear and Sohm (2010) have collected data on prices of paintings, but without performing econometric analysis. Etro and Pagani (2012) have provided a first exploration of data on paintings of the XVII century produced in the main five Italian art centres (Rome, Florence, Venice, Bologna and Naples); however, their analysis was focused on economic history aspects and on the life cycle of the painters, and was based on nominal prices of paintings without adjusting for the cost of living. Etro et al. (2011) have analyzed a matched painter-patron dataset on the Baroque market in Rome focusing on price differentials between genres such as portraits, still lifes, landscapes, genre paintings and figurative paintings. Here we limit our analysis to figurative paintings of the Venetian Republic, we adjust prices for the cost of living to obtain a better measure of the real compensation of the painters, and we investigate additional economic aspects of art pricing.

The article is organized as follows: Sect. 2 describes the market and derives a number of theoretical implications, Sect. 3 presents the dataset and shows the econometric analysis and Sect. 4 concludes.

\section{The Venetian market for figurative oil paintings}

Figurative paintings of sacred, mythological and historical subjects represented the main products of the painters active in Venice. By the mid-XVI century, they were largely painted in oil mainly on rectangular canvases and with simple frames. ${ }^{6}$

Artists were organized in guilds and had to pay an entry fee to access then and trade their paintings under common rules. However, one should not think of the guild as a collusion device: competition was widespread. First of all, most of the leading painters were enrolled, but many low quality painters were able to avoid

\footnotetext{
4 Vaubel (2005) analyses the role of competition in the rise of Renaissance and Baroque music.

5 Some of these works try to characterize the private demand of paintings, and in particular its elasticity with respect to wealth during the 1600s. The wealth elasticity appears above unity in the Low Countries and below unity in Venice. This suggests that paintings were a typical luxury good in the Dutch market, not in the less developed Venetian market (Cecchini, 2000). However, the latter was also characterized by a large religious demand (limited in the Netherlands due to iconoclasm).

6 In the previous centuries, paintings were mainly in tempera on wood panels, covered with a gold background and surrounded by expensive carved and gilded frames. The cost of the woodwork was quite high and typically born by the painters: O'Malley (2005) estimates it between 15 and $30 \%$ of the total price (another $30 \%$ was also spent for gold leafs and gilding). This makes it convenient for us to focus on later paintings whose preparation did not include this cost.
} 
enrollment and practice the art without following the basic rules decided by the guild. $^{7}$

Second, competition was strong and sometimes even predatory, with painters undercutting each other to conquer commissions: during the late 1500s, Tintoretto was an aggressive leader in this market, repeatedly using discounts and preemptive gifts to conquer commissions. ${ }^{8}$ He also kept displaying his works on the streets against a major rule of the guild. Overall, the market could be seen as characterized by competition in prices between differentiated producers and by endogenous entry of these producers (effective mobility was extremely high).

Most commissions were formalized in detailed contracts signed in front of notaries, and defining the price and the mutual responsibilities of the patron and the artist. Early Renaissance contracts (from the XV century) did not require the painter to directly paint the altarpiece: subcontracting was allowed (though rare) except in the presence of Sua mano (his own "hand") clauses (see O'Malley 2005, p. 3). In the more advanced period under our consideration, however, the value of artistic personalities and signatures became more important and all commissions were directly undertaken by the painter, at most with the help of assistants for background and decorative details. Contracts were incomplete, however, because the quality of the paintings could be judged by the commissioner (or by dealers and other painters as advisers), but it could be hardly defined ex ante in the contracts. Painters did care about their reputation, which led them to exert some effort, but the market developed additional incentive mechanisms to limit the conflicts of interests. Many contracts were contingent, involving payment in three tranches, with continued payment being dependent on a positive interim assessment. Some even had a clause affecting the final tranche: it could exceed a contracted-for amount or be less than it, depending on satisfaction. ${ }^{9}$ All this was, however, insufficient to fully solve the conflict of interest between artists and commissioners, and other incentive mechanisms could have emerged.

The demand for oil paintings of religious subject derived mainly from new churches, to decorate their main altar and the lateral chapels (most of which were private and, therefore, under the budget of wealthy patrons) or their naves' walls and ceilings, and from old churches replacing ruined (or stylistically out of fashion)

\footnotetext{
7 According to Cecchini (2000) the enrollment could be seen simply as "an element certifying quality for the artistic work, or a sort of signal of the insiders" to distinguish the masters of the Venetian school from students, occasional imitators and genre painters. For instance, in 1596, the Venetian guild sued two minor painters, Contarini and Malombra for refusing to join the association. They defended themselves claiming that they were only occasional painters practicing painting for delight and not for money. The guild rebutted this showing proofs of payment and the court punished them. Contarini joined the guild in 1597, but Malombra kept painting without enrolling in the guild for other 20 years (see Cecchini 2000, p. 160-161). On the Venetian art market see also Dal Pozzolo and Tedoldi (2003).

${ }^{8}$ In 1564 the Scuola di San Rocco (School of San Rocco) asked a few painters to submit drawings for a ceiling painting. Tintoretto circumvented the competition (of Veronese, Zuccaro and Salviati) installing as a gift a quickly finished painting during the night before adjudication and, with this, he conquered a multi-decade leadership in the decoration of the boardroom, chapter hall and meeting hall of the Scuola. Nevertheless, his prices remained low, as a consequence of the competitive entry pressure that was still present. See Etro (2006) for an economic theory of aggressive leadership in front of entry pressure.

9 Interestingly, the three-tranche structure was already common in fifteenth-century Flemish towns. We are grateful to a referee for comments on these aspects.
} 
paintings. Moreover, demand of religious, historical and mythological subjects derived also from laic patrons: public buildings (such as Palazzo Ducale in Venice or Palazzo della Podestà in Padua) and private collections (as the one of Stefano Conti in Venice in the mid XVII century). Bigger and richer towns, where more churches were built, more prestigious buildings existed and wealthier patrons were active, were clearly demanding more and higher quality paintings.

The supply of paintings depended on the number of painters of different quality available and on their productivity. It is reasonable to expect that the supply of low quality painters was rather elastic, while that of high quality painters, on which we focus, was constrained by the availability of innovative talents in the Venetian market and therefore was more rigid, at least in the short run. ${ }^{10}$ Unfortunately, we do not have reliable measures of productivity, but we will provide a preliminary attempt to build a proxy for productivity based on the number of surviving commissions.

In the rest of this section we describe how other basic factors may have affected demand and supply and therefore the equilibrium price of the paintings, and finally we discuss how to interpret the residual temporal trend of the real compensation of the painters.

\subsection{Aesthetic value and pricing by reputation}

There is no doubt that the aesthetic value of a painting as perceived by its contemporary audience should be the first determinant of its demand and of the final price. However, in a primary market based on commissions, prices are established before the paintings are done and quality can be hardly determined ex ante in a verifiable way. Therefore, prices should depend on the expected quality and its determinants. The main one is the reputation of the painter for producing works of quality. $^{11}$

\footnotetext{
${ }^{10}$ The productivity of the painters had two elements. The first was their ability to produce high quality works, which dependend on talent and also on experience, at least up to a certain age-see Etro and Pagani (2012) for a related discussion on the life-cycle profile of Baroque painters in Italy. The second element of productivity is the rate of production of paintings, whose impact on prices is ambiguous: on one side, more productive painters could be available to reduce their prices, but on the other side a Veblen effect may have taken place (the willingness to pay of the buyers could have been increasing for fashionable painters that produced and sold more paintings).

${ }^{11}$ We have a wide documentary evidence on the reputation of the artists in their ages. A direct account of ranking between painters comes from Guido Reni, probably the most highly regarded painter of the 1600s. In a letter of 1628 he divided painters in three categories of high, medium and low quality, and gave us a witty description of the relation between (his) quality and price. When asked who was the best painter between him and the main competitor Guercino, Guido Reni replied as follows: "I am... and I could tell you the reasons in terms of art but you would not understand them. Therefore these three simple reasons will do. First, because my pictures sell better than his. I, in fact, taught him how to be paid well. Secondly, because he fishes out my ideas and tries to work the way I do. I never followed his way of doing things. On the contrary I've always kept my distance from him. Finally, because all the other artists follow my style and not his" (Spear and Sohm 2010, p. 152). Another treatise by Giovanni Domenico Ottonelli and the painter Pietro da Cortona of 1652, divided artists in three similar categories: those absolutely deserving to be called excellent, those who lived without the benefit of much fame and the pittori infimi.
} 
Each painter can be seen as characterized by a specific style more or less appreciated and priced, therefore we will control for reputation through dummies for the artists, as suggested by Chanel et al. (1996). Interestingly, this allows us to provide a temptative ranking of the painters for the payment they could receive for a representative artwork.

\subsection{Size of paintings and the returns to scale}

A number of empirical studies on modern art auctions have investigated the relation between size of paintings and prices. Anderson (1974) conjectured a relative preference of modern collectors for small paintings and therefore higher prices, but found mixed results in different periods and, overall, an elasticity of the price with respect to size of 0.38 . Subsequent studies on secondary sales have generally found a positive relation for modern and contemporary paintings. ${ }^{12}$

Rengers and Velthuis (2002) find the same for primary sales of contemporary art. However, the relation between price and size of old master paintings may have followed a different logic.

Consider the demand side first. According to Baroque esthetics, the value of art could be hardly measured in square meters. ${ }^{13}$ There is a weak evidence that the willingness to pay of the patrons could increase with the size of paintings. Size was often constrained by a fixed space in the church or in another location, and therefore it was typically exogenous. O'Malley (2005, Ch. 5) provides some documentary evidence for the fact that the willingness to pay of Renaissance commissioners was mainly dependent on elements as their own prestige and "honour" rather than on objective features of the paintings.

On the supply side, size may have been more important. Painters may have taken it in consideration when they were bargaining on prices: if anything, one may think that the cost of the main inputs as labor time, oil colors and help from assistants (often paid by day), should be positively related with the size of paintings, and this should be reflected in prices. However, while costs were increasing in the size, returns to scale were not constant: scale economies were likely to be present. A painting of any size required some time for thinking about the composition and for working on preparatory drawings or a small sketch painting, which justified a less than proportional relation between size and prices. Moreover, even if there was a tendency to fill all parts of a painting with figures and objects (including complex still lifes) and background decorations (either with architectonical settings or landscapes), it is without doubt that larger altarpieces had larger areas that required less work. For this reason, one may expect a positive but concave relation between prices and size.

\footnotetext{
${ }^{12}$ In particular, see the semiparametric partial linear regressions presented by Nahm (2010) for contemporary Korean art.

13 In 1587 the minor painter Giovan Battista Armenini wrote an essay "On the true precepts of the art of painting" supporting the idea that pricing by size debases the noble art of painting and encourages artists to be sloppy and finish too rapidly their paintings. In 1667, the more famous painter Pietro Cortona, while petitioning for a payment for a work in St. Peter's, wrote in third person that "he has never experienced that paintings are bought and sold by the palmo [size] and measurement" (Spear and Sohm 2010, p. 50).
} 
The evidence provided by O'Malley (2005) on the prices of Renaissance altarpieces is in favour of this but inconclusive for the limited size of the sample. ${ }^{14}$

The evidence by Sohm (2010, pp. 240-244) on later Venetian paintings is more reliable for the larger number of observations, but inconclusive for the lack of any control variable. ${ }^{15}$

\subsection{Placement of the paintings and price elasticities}

An interesting determinant of the demand for a painting is its final position: the hierarchy of spaces within churches and buildings may have affected the willingness to pay for paintings and their prices. Looking at Venice, Sohm (2010, p. 235) notices that the "cheapest paintings were placed on ceilings (13 ducats per square meter), closest to heaven but visually marginal, followed by wall paintings (18 ducats per square meter), on average $38 \%$ more than ceiling paintings. Meter-formeter, however, altarpieces brought in the highest prices at over twice as much as ceiling paintings (27 ducats per square meter)." This comparison takes size into account, but of course ignores other aspects. It may be that marginal positions were destined to low quality painters implying lower quality and lower prices, and vice versa for the central positions. What one should verify is whether the same painting was paid more or less only for being destined to a different position.

From an economic point of view, one can easily realize that the demand of oil paintings for altars and ceilings was more rigid than the demand for wall paintings. Oil paintings were by far a forced solution for the decoration of the main altars of churches and chapels, whose number was also exogenously limited, at least in the short and medium run. Ceilings were mostly decorated with frescoes in the rest of Italy, but not in Venice for the problems related with humidity: therefore oil paintings became the standard solution for Venetian ceilings as well. For the decoration of walls, however, Venetian churches and buildings had multiple alternatives available (including sculptures, bronze decorations, tapestry, stucco and wood works). Finally, the space on walls was wider than the space on the altar for obvious architectonical reasons. Therefore, the demand for oil paintings on walls' decoration was much more elastic with respect to the price than the demand for altarpieces and paintings for the ceilings. As a consequence, one may expect that commissioners were ready to give higher monetary incentives to obtain higher quality works for altarpieces and for paintings for ceilings compared to what they were ready to pay for providing incentives to exert extra quality in wall paintings.

\footnotetext{
${ }^{14}$ In the period 1450-1550 the average price of altarpieces between 2 and 4 square meters was 62 gold florins (out of 24 observations), the price between 4 an 7 square meters was 107 florins (for 22 observations), between 7 and 9 was 174 florins (for 9 observations) and between 9 an 12 it was 166 florins (two observations). See O’Malley (2005).

15 The average price of paintings increases with size up to ten square meters. However, above this threshold "the numbers become erratic, dropping by a third or more for sizes between 10 and 25 square meters. Here, mysteriously, it appears that painters were paid less for larger paintings than for smaller ones" (Sohm 2010, p. 241).
} 


\subsection{Number of figures and incentive mechanisms}

There are not deep artistic reasons for which the counting of the human figures in a painting should affect prices, especially if size of paintings and quality associated with each painter are already taken into account in the compensations. Indeed, O'Malley (2005) does not find a positive correlation between price and number of figures during Renaissance (XIV and XV centuries). ${ }^{16}$ At first sight, things do not seem to have changed much in the later period, at least in Venice. Here, Sohm (2010) does not find documentary evidence of an explicit impact of the number of figures on prices. ${ }^{17}$

However, prices may have been decided on the basis of the number of figures even without stating a price per figure in the contracts. Further agreements on the number of figures may have been established in separate notes, letters or even verbal communications. For instance, this happened in one of the rare epistolary negotiations survived until our days and involving the Venetian painters Liberi and Zanchi (see Spear and Sohm 2010, pp. 13-15).

From an economic point of view, there could be an incentive for the adoption of prices increasing in the number of figures. If contracts could not specify quality and moral hazard was a relevant issue (because quality required also costly effort), an explicit or implicit contract maximizing the payoff of the patrons had to be based on other quantifiable variables correlated with quality (Holmstrom 1979). ${ }^{18}$

In the case of figurative paintings, this was possible through the number of human figures: the variety and complexity of the composition, summarized by the number of players, had a positive, though partial, correlation with the final quality. Moreover, painters were often focusing their own effort on human figures and especially on difficult parts as the heads, delegating less relevant parts to their own $\operatorname{assistants}^{19}$ : therefore, a higher number of figures was a proxy for a wider direct intervention of the painters in the overall execution, and consequently for higher quality. Finally, between the main protagonists of each composition, patrons highly valued the presence of their own portraits and those of their relatives and assistants: therefore, a larger number of figures was often a device to introduce portraits that

\footnotetext{
${ }_{16}$ Moreover, she uses documentary, graphic and painted evidence to show that the subject matter of altarpieces was often discussed after signing the contracts, sometimes recorded in separate notes and often changed without affecting the force of the initial contracts. In particular, during Renaissance "the number of main figures planned for a work might be increased after a contract was signed without having any impact upon the fee recorded in the notarial agreement" (p. 136).

17 "Of the 300 or so contracts and many more letters, diaries, etc. that have been gathered for this study, only three (all from the first half of the sixteenth century) give a specific figure price" (p. 244). Moreover, Sohm (2010) does not emphasize any correlation between number of figures and prices in the data. He also provides stylistic explanations for this based on the traditional distinction (going back to Vasari) between the Florentine focus on figure drawing and the Venetian focus on colouring: "What might be concluded from the Venetian tendency to price paintings by size rather than the number of figures? It could be taken to confirm an opinion that Venetian painters considered painting much more than just a figural problem. What constitutes the surface or adheres to it-color and brushwork-are just as important."

18 See Holmstrom and Milgrom (1991) for a classic formulation of the principal-agent theory.

19 For instance, detailed documentary evidence of this division of work is available for the workshop of Strozzi (Cecchini, 2000, p. 164).
} 
could please the patrons and enhance their perception of quality. Etro et al. (2011) and Etro and Pagani (2012) have supported the same idea in related investigations of Italian paintings of the XVII century, but here we test the hypothesis within a more detailed empirical model.

\subsection{The law of one price}

If painters could freely work and move, we may expect that, at each point in time, a canvas of given size painted by a given painter should have the same price whatever was its subject and wherever it was sold. We can test the first hypothesis looking at figurative paintings of different subjects, such as sacred subjects, mythological (and allegorical) subjects, historical subjects (including literary and heraldic ones) and battles, and asking whether, after controlling for demand and supply conditions, price equalization did hold. In spite of substantial differences between average nominal prices (193 ducats for religious paintings, 153 for mythological ones, 184 for historical ones and 329 for the battles) we will confirm that price equalization between subjects did hold. Etro et al. (2011) have investigated a similar hypothesis in Baroque Rome, finding price equalization not only between different subjects of figurative paintings, but also between figurative paintings and other artistic genres such as still lifes, portraits, genre paintings and landscapes.

The second hypothesis requires a look at the points of sale of the paintings. A standard common-place in art history is that prices were higher in the major cities because income and demand were higher compared to smaller towns or to the countryside. $^{20}$ O'Malley (2005, p.136-142) looks at a very limited dataset on Renaissance altarpieces suggesting that prices in Florence were higher than in the rest of Central Italy and Venice (but lower than in Rome) in the second half of the $\mathrm{XV}$ century, but the relation reversed in the first half of the XVI century. Comparisons between main art centres and countryside are even less conclusive for the limited size of the sample and the lack of controlling factors. "Before 1450, prices in Florence and Siena were higher than those paid in provincial towns, but in the later fifteenth century the contrary was the case, and Florentine prices continued to be lower than those in provincial towns in the early sixteenth century. Venetian painters may have had an opposite experience, that is, between 1450 and 1500, prices may have been lower in Venice than they were on the mainland, but the sample is very small and conclusions are tentative. After 1500, prices in Venice seem to have been higher than those paid in the Venetian provinces" (O'Malley, 2005, p. 142). Looking at average nominal prices in the subsequent two centuries, Sohm (2010, pp. 234-235) finds that Venice priced at 218 ducats, Vicenza at 148, Verona at 119 and other minor Veneto towns at 126, while Bergamo reached a higher average price of 360 ducats. Moreover, he finds justifications for the outliers: "Bergamo places first because the deputati of S. Maria Maggiore were both wealthy

\footnotetext{
${ }^{20}$ In 1625, Fra Atanasio, an art dealer who was negotiating an altarpiece by the painter Cerano in Milan, told the patron that the painter would have probably accepted $250 \mathrm{scudi}$, but also that if Cerano were to go to Rome he would be paid 500 scudi, claiming the existence of a high price differential between a large art centre such as Rome and a smaller (but not even peripherical) centre such as Milan (Sohm 2010, p. 233).
} 
and ambitious. The bottom ranking of Verona confirms Scipione Maffei's account in 1732 of seventeenth century Verona as a cultural backwater." These considerations must have been relevant, but from an economic point of view the high mobility of painters suggests that important adjustment mechanisms should have been at work to equalize prices. To test for this we need to verify if the compensation in real terms was significantly different between different points of sale after controlling for all demand and supply features.

Such a test of the law of one price is somewhat related to the test for price differentials in contemporary auctions located in different towns and held by different auction houses (such as Sotheby's and Christie's versus minor ones): results in those cases are mixed (Chanel et al. 1996; Dorchy and Ginsburgh 1993), but one should keep in mind that the market for auctions is highly concentrated and the two dominant companies can adopt differentiated strategies in selecting and pricing objects. This was not the case for the points of sale of our paintings.

\subsection{Temporal trends}

A large part of the literature on modern art pricing has been focused on estimating the return from the investment in art from data on secondary sales (Anderson, 1974; Baumol, 1986; Frey and Pommerehne 1989; Locatelli-Biey and Zanola 1999; Mei and Moses 2002).

Looking at data on primary sales, the focus must shift to the simple trend of the prices in the market, which can derive from economic mechanisms, but can also shed light on art historical issues. Ideally, after controlling for all the determinants of demand and supply of the paintings and the painters, a temporal trend of the equilibrium real compensations for paintings of given features should reflect real changes in the remuneration of the artistic activity over time. Given the number of painters active in a region and their productivity, an increase in the real compensation should reflect increased demand, which could attract painters from other regions or, in the long run, induce more talents to follow the artistic career. If this is the case, temporal trends due to demand shifts may generate endogenous artistic consequences.

The analysis of the time trend for Venetian paintings over two centuries may provide new insights on the artistic cycles of this region. In particular, it may contribute to explain the alternance of two periods of innovative creativity (for an art historical account see Sohm, 2010). The first is the golden age of Venetian art started with the innovations of Renaissance masters such as Antonello da Messina, Giovanni Bellini, Giorgione and the young Titian, and continued with the work of Mannerist masters such as the older Titian, Veronese and Tintoretto. In particular, Antonello introduced oil colors in Italian art, Giorgione and Titian introduced artistic innovations in the use and mix of colors (that led Vasari to speak of a Venetian school focused on color, distinct from the Florentine school focused on drawing), and Veronese and Tintoretto pushed this to its limits, introducing respectively a new radiant palette and a new sketchy style which will be largely copied during the following periods. After the death of the three main mannerist masters, the Baroque century is usually regarded as a dark age of Venetian art, in 
which even the leading painters kept imitating the style of the Mannerist masters without introducing substantial innovations and remaining largely unaffected by the artistic ideas emerging in Rome at the same time. It was only at the turn of the century that a second renaissance of Venetian art took place and a new style based on the bright and sparkling colors used by Tiepolo in his frescoes and Ricci in his canvases influenced the international Rococò style, while the vedute by Canaletto (who started employing a camera obscura to achieve maximum accuracy) were renovating the landscape genre.

In a Schumpeterian perspective, such a path of artistic innovations could be have been driven by a U-shaped pattern of the real compensations for painters in the Venetian Republic: decreasing compensations from the artistic activity between the end of the XVI century and the beginning of the XVII century could have motivated lower engagement and innovation in the Venetian art market during the Baroque age compared to the earlier Mannerist phase, and increasing returns during the end of the XVII century and the beginning of the XVIII century could have motivated the more dynamic artistic creativity of the Rococò period. ${ }^{21}$

Aggregate phenomena may have been in the background: the gradual decline of Venice as an economic power during the 1500s induced a decline in the Venetian aggregate demand, and the emerging globalization during the 1700s induced a recovery of the aggregate demand.

\section{Data and empirical analysis}

The data used for the empirical analysis are drawn from original commissions to painters. The main source of the dataset is Sohm (2010), who collected data on prices (from original contracts and other documentary evidence) and other characteristics of 254 oil paintings made between 1551 and 1746 by 61 artists located in the Venetian Republic (see Table 1 for a list of the artists). ${ }^{22}$

We can fairly look at the sample as representative of the (many more) commissions for oil paintings that took place at the time. The main reason is that the survival of documentary evidence on these contracts for about four centuries is largely random: fires, wars and other accidental events have spread losses of documents across all the original archives.

Prices are expressed in Venetian silver ducats. The second half of the XVI century was characterized by a sustained inflation (due to the arrival of silver from the Americas), and the first half of the XVIII century exhibited wide price variability. Therefore, we take into account changes in the price level over the two

\footnotetext{
21 Notice that such a pattern for the real compensation of paintings is not trivial, because nominal prices of Italian paintings appear to be constant or slightly increasing during the same period (Etro and Pagani, 2012). Moreover, preliminary investigations on paintings in Rome show the opposite pattern: an inverse $\mathrm{U}$ shape of the real compensations, which is actually consistent with the pick of creativity in Rome during the early XVII century.

22 We checked one by one the data, especially to separate multiple commissions (which required information on size of the paintings and number of figures). We also added additional data concerning the age of painters at the time of execution and other qualitative features from standard art history sources.
} 
Table 1 Artists included in this study, mean price and number of observations

\begin{tabular}{|c|c|c|}
\hline Artist & $\begin{array}{l}\text { Mean price } \\
\text { (silver ducats) }\end{array}$ & $\begin{array}{l}\mathrm{Nr} \text { of } \\
\text { observations }\end{array}$ \\
\hline Titian (1489-1576) & 343 & 4 \\
\hline Franco (1500-1561) & 60 & 1 \\
\hline Campagnola (1500-1564) & 78 & 1 \\
\hline Ponchino (1500-1570) & 270 & 1 \\
\hline Schiavone (1510-1563) & 60 & 1 \\
\hline $\begin{array}{l}\text { Bassano, J. (1510-1592) } \\
\text { and L. (1557-1622) }\end{array}$ & 80 & 6 \\
\hline Brusasorci (1516-1567) & 78 & 1 \\
\hline Michieli (1516-1578) & 130 & 2 \\
\hline Tintoretto (1518-1594) & 82 & 24 \\
\hline Salviati G. (1520-1575) & 60 & 1 \\
\hline Vecellio, C. (1521-1601) & 81 & 2 \\
\hline Moroni (1522-1578) & 405 & 1 \\
\hline Farinati (1524-1606) & 45 & 26 \\
\hline Licinio (1527-1591) & 60 & 1 \\
\hline Veronese (1528-1588) & 113 & 11 \\
\hline Varotari, D. (1539-1596) & 44 & 1 \\
\hline Zuccaro (1539-1609) & 1,000 & 1 \\
\hline Palma the Younger (1548-1628) & 244 & 28 \\
\hline Bassano, F. (1549-1592) & 57 & 4 \\
\hline Cavagna (1556-1627) & 56 & 4 \\
\hline Maganza (1556-1640) & 9 & 1 \\
\hline Tintoretto, D. (1560-1635) & 150 & 1 \\
\hline Marco Vicentino (1573-1638) & 140 & 1 \\
\hline Maffeo Verona (1576-1618) & 30 & 1 \\
\hline Turchi (1578-1649) & 296 & 1 \\
\hline Strozzi (1581-1644) & 32 & 1 \\
\hline Padovanino (1588-1649) & 136 & 3 \\
\hline Prudenti (1591-1665) & 350 & 1 \\
\hline Renieri (1591-1667) & 61 & 1 \\
\hline Heintz (1600-1678) & 200 & 1 \\
\hline Vecchia (1602-1678) & 150 & 1 \\
\hline Maffei (1605-1660) & 120 & 6 \\
\hline Liberi (1605-1687) & 363 & 6 \\
\hline Ricchi (1606-1675) & 151 & 4 \\
\hline Massimo da Verona (1607-1679) & 221 & 1 \\
\hline Ruschi (1610-1661) & 297 & 3 \\
\hline Carpioni (1613-1678) & 65 & 2 \\
\hline Beverensi (1624-1694) & 60 & 1 \\
\hline Triva (1626-1669) & 76 & 2 \\
\hline Zanchi (1631-1722) & 287 & 19 \\
\hline Loth (1632-1698) & 726 & 1 \\
\hline
\end{tabular}




\begin{tabular}{llc}
\hline Artist & $\begin{array}{l}\text { Mean price } \\
\text { (silver ducats) }\end{array}$ & $\begin{array}{l}\text { Nr of } \\
\text { observations }\end{array}$ \\
\hline Giordano (1634-1705) & 290 & 2 \\
Celesti (1637-1712) & 154 & 10 \\
Fumiani (1645-1710) & 100 & 4 \\
Pittoni, F. (1645-1724) & 44 & 1 \\
Prunato (1654-1728) & 170 & 1 \\
Dorigny (1654-1742) & 198 & 1 \\
Molinari (1655-1704) & 105 & 2 \\
Trevisani (1656-1746) & 600 & 1 \\
Lazzarini (1657-1730) & 75 & 5 \\
Ricci (1659-1734) & 352 & 20 \\
Marchesini (1663-1738) & 150 & 1 \\
Canziani (1664-1730) & 120 & 1 \\
Balestra (1666-1740) & 245 & 6 \\
Bellotti, G.B. (1667-1730) & 170 & 1 \\
Pellegrini, G.A. (1675-1741) & 270 & 1 \\
Piazzetta (1682-1754) & 141 & 2 \\
Grone (1685-1750) & 58 & 1 \\
Pittoni, G.B. (1687-1767) & 417 & 8 \\
Tiepolo (1696-1770) & 466 & 1 \\
\hline
\end{tabular}

When the birthdate is uncertain from historical sources, the best estimate is used

centuries under consideration. To this aim, we convert nominal prices in real terms by first changing ducats in the units of account, the liras (according to the exchange rate of 1 ducat per 6.4 liras), and, secondly, by using information regarding the quantity of Venetian liras necessary to buy a hundred kilograms of wheat, as calculated by Malanima (2002) for each decade. Better inflation indexes are not available, but wheat was an essential good for most of the population and its price variations were likely to be reflected in those of many other goods. Using this procedure we translate nominal prices in real terms reflecting the cost of living and its changes during the period under analysis and, thus, we base our econometric investigation on a more reliable measure of artworks values, that is on ducats' purchasing power.

Important information on artworks' characteristics that potentially influence the price is available in the dataset or was collected by us: author, title, subject (sacred, mythological, historical or a battle), size of the painting, number of figures included in the composition, town and building where it was planned to be located, position in the building (i.e. on a main or secondary altar, on the ceiling, or on lateral walls including the organ), commissioner's type, that is whether the artwork was made for a religious or for a secular commissioner, date of commission and age of the artist when the painting was made. We cannot control directly for the productivity of the painters because we have estimates of the number of paintings produced only for the most famous ones; nevertheless, we can use the information on the ratio between the number of paintings of each artist in the dataset and the length of his/her artistic 
life (within the time-frame of the dataset): if our sample is a random sample of the production of the time, this ratio should be positively correlated with the productivity of the artists.

Tables 2 and 3 show a partial list of the variables we used in the empirical analysis together with their main summary statistics. Given that many of the continuous variables we used are not normally distributed, in order to better describe them in addition to their mean and standard deviation we report also their maximum and minimum values, the median, the skewness and the kurtosis. The average price of a painting was 193.5 Venetian silver ducats, while the median value was much lower (100 silver ducats). However, a large variation in prices can be observed, with prices ranging between a minimum of 5 to a maximum of 2,306 silver ducats. To get a clearer picture of the price distribution in our sample, the histogram in Fig. 1 illustrates the class-price distribution. The modal price value was between 50 and 100 silver ducats, with around $27 \%$ of observations; another $24 \%$ of the paintings were paid less than 50 silver ducats while less than $20 \%$ were paid more than 300 ducats. Also painting's size and the number of figures vary a lot across paintings and their distribution is far from being a symmetric one: the average painting's size is 12.4 square meters but while the smallest painting in the dataset measures 0.4 square meters, the largest size is around 85 square meters. The average oil painting contains 10 figures; nonetheless, the number ranges from 1 figure to the 59 figures of Tintoretto's Last Judgement. Around $40 \%$ of the sample is made by artworks whose final location is lateral wall of a church or a secular building, altarpieces account for $53 \%$ of the paintings, almost entirely in churches, and paintings for the ceiling are $7 \%$ of the total.

In our empirical analysis the dependent variable is the ratio between the price of painting $i$ executed at time $t$ by painter $j, p_{i j t}$, and the price of wheat at time $t, P_{t}$. Our baseline regression is the following:

$$
\ln \left(\frac{p_{i j t}}{P_{t}}\right)=\alpha+\beta X_{i j}+\gamma \text { Artist }_{j}+\delta_{1} a g e_{i j}+\delta_{2} a g e_{i j}^{2}+\theta_{1} t_{i j}+\theta_{2} t_{i j}^{2}+\varepsilon_{i j}
$$

where we control for a number of characteristics of the paintings, for artist dummies, for the life-cycle of the painters with a linear and a quadratic term in the age of the painter at the time of the commission, and for the time trend through a quadratic specification. We also perform a number of robustness checks. First of all, we model the determinants of prices across two levels: paintings and artists, adopting a multilevel linear regression approach as in Rengers and Velthuis (2002). More

Table 2 Summary statistics-continuous variables

\begin{tabular}{lrlccccc}
\hline Variables & Mean & Median & Min & Max & Std Dev & Skewness & Kurtosis \\
\hline Price & 193.5 & 100 & 5 & 230 & 245.8 & 4.0 & 28.1 \\
Size & 12.4 & 6.9 & 0.4 & 84.8 & 14.1 & 2.6 & 10.7 \\
Nr figures & 9.8 & 7 & 1 & 59 & 9.4 & 2.6 & 11.3 \\
Age & 52.2 & 51 & 22 & 81 & 13.6 & 0.0 & 2.0 \\
NP/AL & 0.26 & 0.27 & 0.01 & 0.56 & 0.18 & 0.19 & 1.65 \\
\hline
\end{tabular}


Table 3 Summary statisticsdiscrete variables

\begin{tabular}{lll}
\hline Variables & Mean & Std Dev \\
\hline Religious commissioner & 0.76 & 0.43 \\
Altar & 0.53 & 0.50 \\
Wall & 0.40 & 0.49 \\
Ceiling & 0.07 & 0.26 \\
Venice & 0.41 & 0.49 \\
Minor destination & 0.22 & 0.42 \\
Verona/Vincenza & 0.15 & 0.36 \\
Bergamo & 0.05 & 0.22 \\
Padua & 0.04 & 0.20 \\
Foreign destination & 0.10 & 0.30 \\
Treviso & 0.03 & 0.17 \\
Sacred & 0.82 & 0.38 \\
History & 0.07 & 0.26 \\
Myth & 0.07 & 0.26 \\
Battle & 0.03 & 0.16 \\
\hline
\end{tabular}

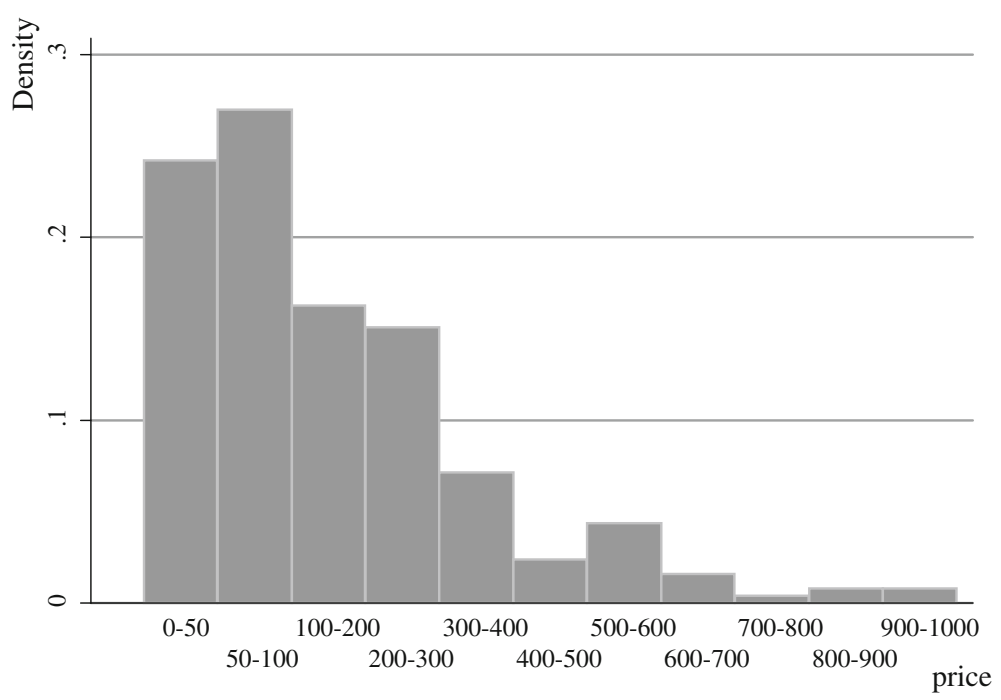

Fig. 1 Distribution of paintings' prices in silver ducats

specifically, we estimate a fixed-effects model that includes explanatory variables at both artist and painting levels. In this way, we shift the regression line up or down according to each artist so that the fitted regression line for a given artist will differ from the average line in its intercept. ${ }^{23}$

\footnotetext{
23 The multilevel model is estimated as a robustness check although our preferred model is the OLS, given that in many cases we have very few paintings per artist.
} 
Second, we control for the time trend through 10-year time dummy variables in order to compare the non-parametric specification to our quadratic specification. Finally, we refine the baseline regression introducing dummies for the different figurative genres (sacred, mythological, historical, and battles) and the ratio between the number of paintings of each artist in the dataset and the length of his/her artistic life (NP/AL) as a rough measure of artists' productivity. ${ }^{24}$

Table 4 shows OLS estimates of the price equation. Coefficients of the artist fixedeffects based on the baseline specification of Table 4 (columns 1-2) are shown in Table 5. The first remarkable thing to notice is that the adjusted $R^{2}$ is equal to $73 \%$ in the baseline regression, pointing out a good overall fit and providing first evidence of the existence of a systematic pattern in the process of price determination (in line with studies that control for a similar number of factors including the artist dummies, such as Chanel et al. 1996; Dorchy and Ginsburgh 1993; Nahm, 2010). ${ }^{25}$

Moreover, generally the estimated parameters take the expected sign. The artist dummies rank the painters for their compensation in terms of comparable purchasing power from selling a representative painting (see Table 5): from the top we find Ruschi, Liberi, Giordano, Zanchi, Balestra, Triva, Palma the Younger, Michieli and Ricci (the omitted one is Farinati, the least paid artist of the sample). It is remarkable that some of the most famous painters (according to our contemporary evaluation) appear only in the middle of the ranking and, overall, the price differentials between painters appear to be rather limited (at least compared to the differentials in prices today). Prices appear increasing and concave in the age of the painters, in line with what found by Etro and Pagani (2012) for Baroque Italy. The age of maximum appreciation in the market $A g e^{*}=\hat{\delta}_{1} / 2 \hat{\delta}_{2}$ can be calculated as 74 years.

The results highlight a premium of around $9 \%$ per square meters and thus they confirm that larger paintings were paid more. Additionally, we find evidence of weak scale economies in the production technology, as suggested by the negative and significant coefficient of squared size. In terms of elasticity of the price with respect to size, we obtain an elasticity of 0.5 which is actually in line with what obtained for investigations on secondary sales in modern auctions (since Anderson, 1974). The number of figures plays a key role for price formation. More specifically, each figure brings an increase in painting's price of around $3 \%$ (we entered also the square term but the coefficient was not nearly statistically significant). As pointed out before, there can be a contractual rationale behind this result to limit the moral hazard of the painters (because the number of human figures was a proxy for the effort of painters).

Another factor correlated with the price of paintings addressed to churches was the position where they were planned to be placed (in secular buildings the paintings were mainly on the walls). In the estimated equation the excluded category is Altar,

\footnotetext{
${ }^{24}$ As noticed by a referee, the lack of information on the total number of commissions (even neglecting quality differences between them) and on the exact nature of the activity within each workshop makes it impossible to obtain correct measures of productivity. Our index is only meant to provide a preliminary attempt to control for productivity.

${ }^{25}$ We re-estimated the model without artists' fixed-effects and we found an adjusted $R^{2}$ equal to $64 \%$, suggesting a good fit also reducing considerably the number of the explanatory variables included.
} 


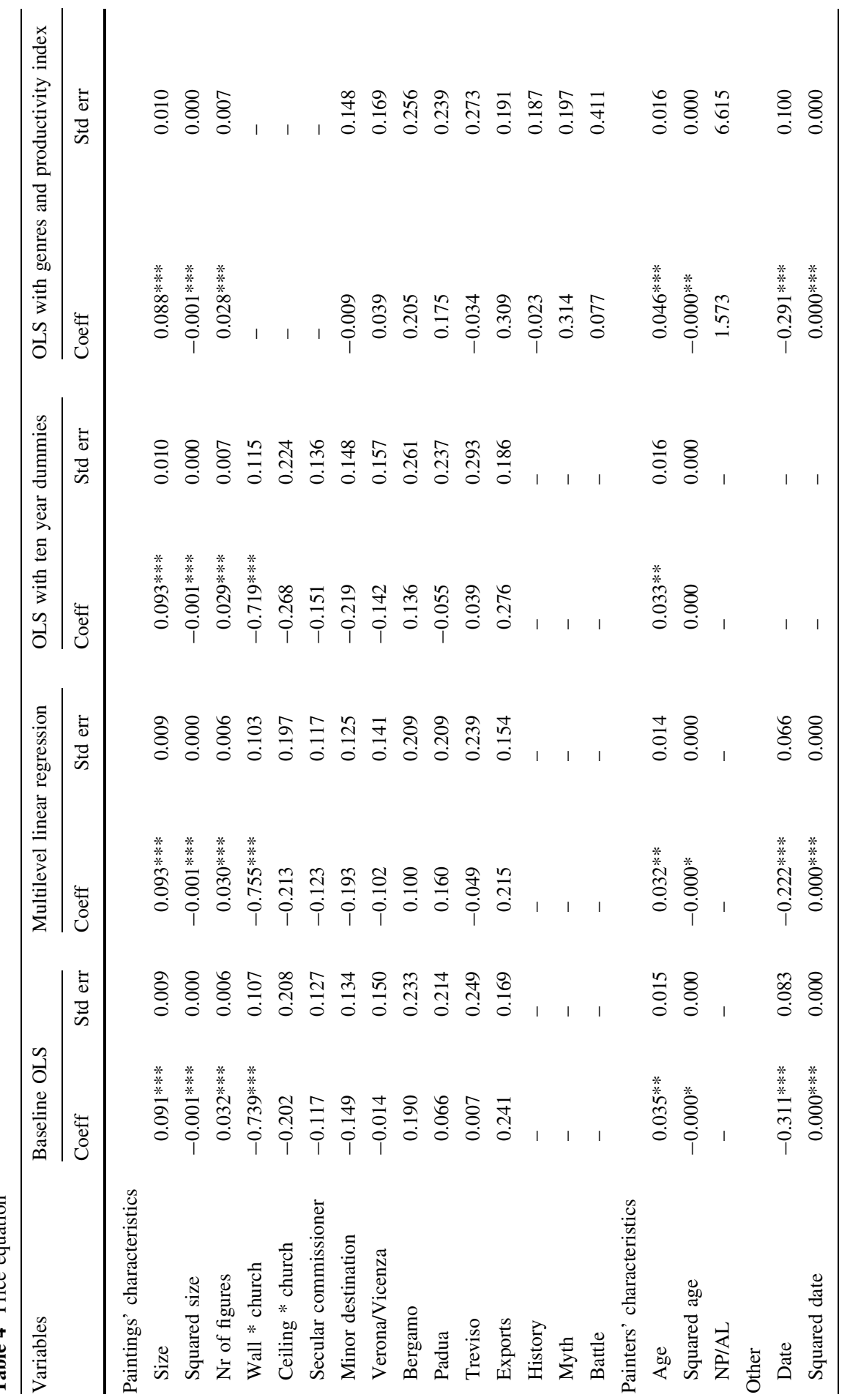




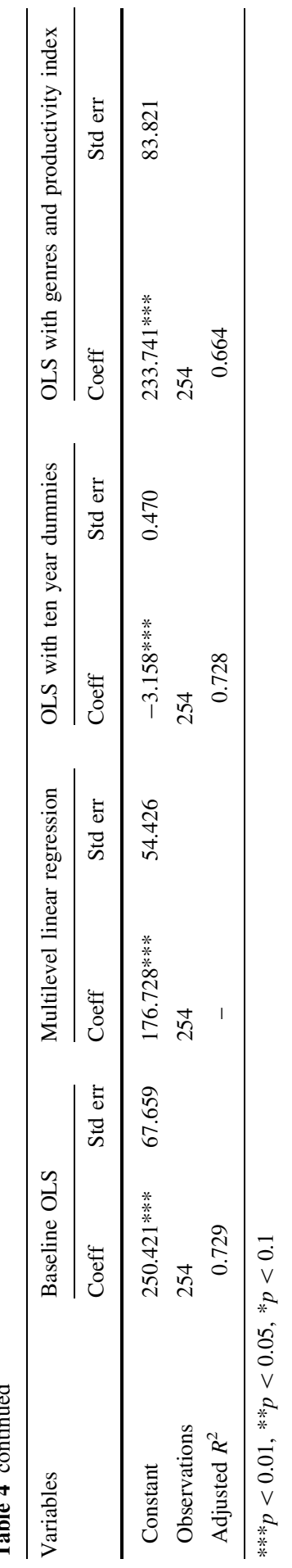


Table 5 Artist fixed effects

\begin{tabular}{|c|c|c|c|}
\hline Table 5 Artist fixed effects & \multicolumn{2}{|r|}{ Coeff } & \multirow{2}{*}{$\frac{\text { Std err }}{0.388}$} \\
\hline & Balestra & $1.410 * * *$ & \\
\hline & Bassano & 0.206 & 0.306 \\
\hline & BassanoF & 0.188 & 0.385 \\
\hline & Carpioni & $0.756^{*}$ & 0.457 \\
\hline & Cavagna & 0.358 & 0.388 \\
\hline & Celesti & $0.668^{* *}$ & 0.310 \\
\hline & Fumiani & $0.760^{*}$ & 0.398 \\
\hline & Giordano & $1.616^{* * *}$ & 0.504 \\
\hline & Lazzarini & $1.119 * * *$ & 0.407 \\
\hline & Liberi & $1.799 * * *$ & 0.309 \\
\hline & Maffei & $0.818^{* *}$ & 0.327 \\
\hline & Michieli & $1.232 * * *$ & 0.453 \\
\hline & Molinari & $0.939^{*}$ & 0.505 \\
\hline & Padovanino & $0.972 * *$ & 0.402 \\
\hline & Palma Giovane & $1.242 * * *$ & 0.200 \\
\hline & Piazzetta & 0.887 & 0.541 \\
\hline & PittoniGB & $1.055^{* *}$ & 0.437 \\
\hline & Ricchi & $1.173 * * *$ & 0.375 \\
\hline & Ricci & $1.203^{* * *}$ & 0.336 \\
\hline & Ruschi & $2.117 * * *$ & 0.416 \\
\hline & Tiepolo & 0.687 & 0.434 \\
\hline & Tintoretto & $0.397 * *$ & 0.201 \\
\hline & Titian & $0.965 * *$ & 0.380 \\
\hline & Triva & $1.253^{* *}$ & 0.510 \\
\hline & VecellioC & $0.996^{* *}$ & 0.433 \\
\hline & Veronese & $0.686^{* * *}$ & 0.255 \\
\hline & Zanchi & $1.522 * * *$ & 0.268 \\
\hline & Constant & $250.421 * * *$ & 67.659 \\
\hline & Observations & 254 & \\
\hline$* * * p<0.01, * * p<0.05$ & Adjusted $R^{2}$ & 0.729 & \\
\hline
\end{tabular}

$* * * p<0.01, * * p<0.05$ $* p<0.1$

so that the negative and highly statistically significant coefficient of the Wall dummy variable points out that artworks produced for this kind of location were paid much less than altarpieces $(-73 \%)$. As explained in the previous section, because of the presence of a larger number of substitutes for decoration of lateral walls, especially in churches, the demand elasticity was higher for paintings for walls than for both altars and ceilings. For this reason, commissioners were ready to give lower monetary incentives for quality in paintings destined to lateral walls. On the other hand, we do not find any statistically significant difference between prices of altarpieces and ceilings, whose demand was more rigid (because of the lack of substitute decorations and the limited space available for these artworks). Looking at the impact of the commissioner, we do not find any statistically significant 
difference between prices of paintings addressed to secular buildings and altarpieces, while churches' wall paintings were considerably less paid. Table 4 shows also that the main results do not change, neither in terms of coefficients' value nor in their statistical significance, when we adopt a multilevel linear regression approach (columns 3-4) and when we control the time trend with tenyear dummies (columns 5-6).

The point of sale of the paintings did not matter for the compensation of the painters in real terms. This result is consistent with the hypothesis that the structure of this market was endogenous in general equilibrium and painters' mobility was arbitraging away price differentials between towns with different demand sizes. As a matter of fact, in a dynamic perspective any price differential should induce painters to move toward high price geographical destinations (or send their works there), which would tend to put downward pressure on the prices of those geographical destinations and to increase the prices of the other ones. ${ }^{26}$

Most important, also exported paintings were not paid more in absolute terms, ${ }^{27}$ but foreign commissioners were simply selecting higher quality paintings by high quality painters, which is in line with the selection effect pointed out by the literature on heterogeneity between producers in trade. ${ }^{28}$

The law of one price is also confirmed when we include dummies for different subjects such as sacred, mythological and historical paintings or battles (see columns $7-8$ of Table 4; sacred paintings are the reference group $)^{29}$ : price equalization between different subjects appear to hold, confirming what found by Etro et al. (2011) not only for this subject classification of figurative paintings but also for different genres of paintings (figurative versus still lifes, portraits, landscapes and so on) in Baroque Rome. It should be noticed that the ratio between the number of commissions for each painter in the dataset and the length of the career of the painter is not correlated with prices and does not affect the other results: more accurate investigations on the level of productivity of the painters and how this could affect prices would be useful.

Finally, let us look at the temporal trend. The date variable is entered as a secondorder polynomial. We find a negative and significant coefficient for the linear term and a positive and significant coefficient for the quadratic term, showing that, ceteris paribus, prices were high in late Renaissance and a phase of price decrease at the beginning of the period under analysis was followed by a stage of growth in prices. We also re-estimated the model including 10-year time dummy variables to check for robustness of our results and indeed we find that they are largely unchanged (see

\footnotetext{
${ }^{26}$ See Etro and Colciago (2010) for a recent investigation of endogenous market structures in general equilibrium models.

27 As noted by a referee, there may have been more uniformity of taste across the Italian cities than was the case internationally, therefore price equalization between Italian and foreign markets provides a stronger test for our hypothesis.

28 See Melitz (2003).

29 In the last specification we omitted the dummies on the placement of the paintings because all mythological paintings and most historical ones were for secular commissioners. We controlled also for differences between the particular subjects of the paintings (including Christ, scenes of the Annunciation or the Nativity), but neither coefficient was statistically significant.
} 


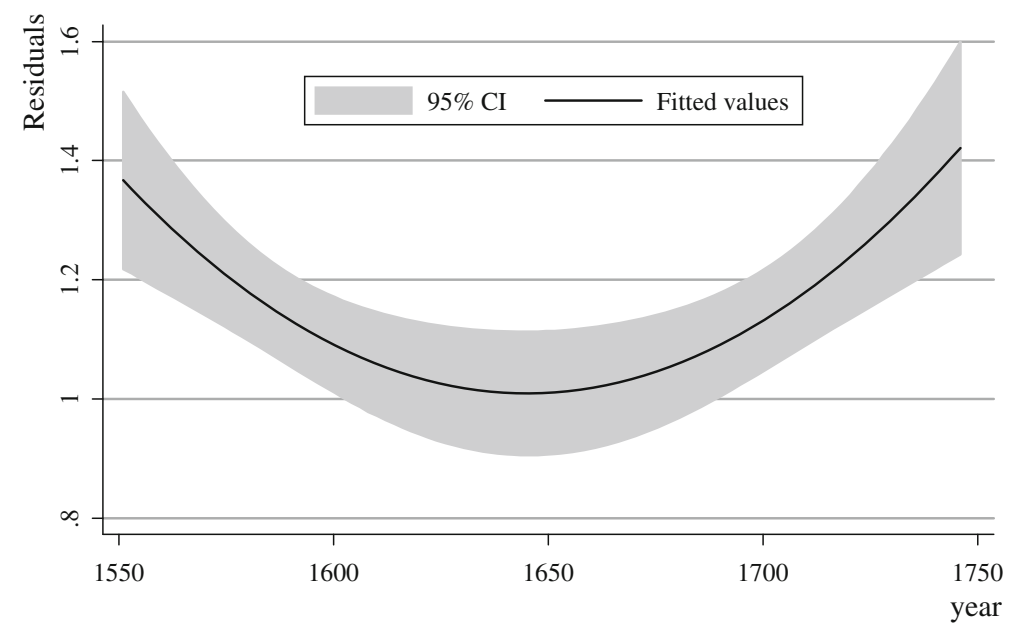

Fig. 2 Price time trend

columns 5-6 of Table 4). In order to get a clearer picture of the price time trend, we re-estimate the baseline equation excluding date and its square and we predict residuals. In Fig. 2 we plot these residuals on date and its square along with their confidence interval. The plot clearly shows that the profitability of painting decreased gradually throughout the first half of the XVII century and started growing afterwards. The year of minimum compensation for artworks can be estimated as $t^{*}=\hat{\theta}_{1} / 2 \hat{\theta}_{2}$ which corresponds to 1634 , when the price of a representative painting in real terms was approximately $40 \%$ lower than a century before and a century later.

This result is potentially consistent with the Schumpeterian hypothesis that prices affected not only the (endogenous) number of active painters, but also their search for innovation, productivity and quality: during the sixteenth century, Venice knew a period of artistic magnificence exemplified by the innovations in the use of color by Titian, Veronese and Tintoretto, and followed by a strong decline that lasted through most of the following century (in which leading painters were constantly replicating the old style). However, at the beginning of the 1700 s, a new phase of grandeur in visual art started, with the innovative works by Tiepolo in fresco decorations and Canaletto in cityscapes. These shifts to different artistic phases may be red in terms of the endogeneity of the entry decision in the art market. The late XVI century was characterized by high supply of local innovative talents ${ }^{30}$ and decreasing demand associated with the decline of the Venetian commercial leadership, which contributed to reduce art prices and, possibly, to generate artistic decline. The late XVII century and early XVIII century, instead, was characterized by limited supply of local painters and increasing globalization of the art market

\footnotetext{
30 Many of them moved from the countryside to Venice exactly to expoit profitable opportunities, such as Veronese, Massimo da Verona and Maffeo Verona from Verona, Titian from Pieve di Cadore, the Bassano's from Bassano del Grappa, Padovanino from Padua (while Tintoretto was Venetian).
} 
which lead to new foreign demand ${ }^{31}$ and higher prices: this, in turn, may have fostered the artistic rebirth.

After all, the choice to become a painter required some talent and a long training, but, as any occupational choice, it was largely determined by economic motivations, namely by its expected compensation. While in the short run painters' quality determines prices, in the medium and long run prices may contribute to attract entry and determine innovative activity and, therefore, higher quality in traditional genres (or introduction of new genres). More important from a cultural point of view, if prices and profits were indeed a source of artistic innovation, then one of the determinants of the path of art history may have been the endogenous structure of the art market. As the painter and art critic Vasari wrote in his "Lives of the Most Excellent Painters, Sculptors, and Architects" (1568), "if in our century there were enough profits, we would paint greater and better works than the older masters." The same Vasari was the first to mention "competition" as one of the sources of Florentine leadership in Renaissance art. Obviously, our evidence provides only a very weak test for this hypothesis, but it points out few suggestions for future research on the analysis of the endogenous entry of painters in the art market.

\section{Conclusion}

We have studied the real compensations of painters for important commissions in the Venetian Republic from Renaissance to the Rococò age. Our main purpose was to show that looking at the market for paintings as a full fledged market and analyzing the contractual aspects of its sales and the endogeneity of its structure could shed light on the determination of the prices of some of the most valuable handmade objects of humankind. This is one of the first attempts at investigating primary markets for art in the past centuries: we believe that additional empirical analysis may shed new light on our understanding of old and modern art markets and open a new research space for quantitative explorations in the field of art history.

Acknowledgments We are thankful to Philip Sohm for extensive comments, and Isabella Cecchini, James Heckman, David Galenson, Francis Kramarz, Silvia Marchesi, Noemi Pace and Richard Spear for helpful remarks. The Editor and two anonymous referees provided important comments.

\section{References}

Anderson, R. (1974). Paintings as an investment. Economic Inquiry, 12(1), 13-26.

Bajari, P., \& Benkard, L. (2005). Demand estimation with heterogeneous consumers and unobserved product characteristics: A hedonic approach. Journal of Political Economy, 113(6), 1239-1276.

Bartik, T. (1987). The estimation of demand parameters in hedonic price models. Journal of Political Economy, 95, 81-88.

Baumol, W. (1986). Unnatural value: Or art investment as floating crap game. American Economic Review, 76(2), 10-14.

\footnotetext{
31 Not by chance Venice started exporting painters (such as Ricci and Tiepolo), while Canaletto had a stable demand from foreign turists visiting Venice.
} 
Brown, J., \& Rosen, H. (1982). On the estimation of structural hedonic models. Econometrica, 50, $765-768$.

Buelens, N., \& Ginsburgh, V. (1993). Revisiting baumol's unnatural value, or art as investment as a floating crop game. European Economic Review, 37(7), 1351-1371.

Cecchini, I. (2000). Quadri e Commercio a Venezia durante il Seicento. Venice: Cini Foundation.

Chanel, O., Gérard-Varet, L.-A., \& Ginsburgh, V. (1996). The relevance of hedonic price indices, The case of paintings. Journal of Cultural Economics, 20, 1-24.

Dal Pozzolo, E., \& Tedoldi, L. (Eds.). (2003). Tra Committenza e Collezionismo. Venice: Cini Foundation.

De Marchi, N. (1995). The role of Dutch auctions and lotteries in shaping the art market(s) of 17thcentury Holland. Journal of Economic Behavior \& Organization, 28, 203-221.

Dorchy, L., \& Ginsburgh, V. (1993). Price trends for English and French silver. Arts, Antiques, Auctions, $240,152-155$.

Etro, F. (2006). Aggressive leaders. RAND Journal of Economics, 37(Spring), 146-154.

Etro, F., \& Colciago, A. (2010). Endogenous market structures and the business cycle. Economic Journal, 120(549), 1201-1234.

Etro, F., Marchesi, S. \& Pagani, L. (2011). The labor market in the seventeenth century Italian art sector, University of Venice, Ca' Foscari, Department of Economics, W.P. 23.

Etro, F., \& Pagani, L. (2012). The market for paintings in Italy during the seventeenth century. Journal of Economic History, 72(2), 423-447.

Fantoni, M., Matthew, L., \& Matthews-Grieco, S. (Eds.). (2003). The Art Market in Italy. Ferrara: Panini.

Frey, B., \& Pommerehne, W. (1989). Muses and Markets. Explorations in the economics of the arts, Oxford: Blackwell.

Galenson, D., \& Weinberg, B. (2000). Age and the quality of work: The case of modern American painters. Journal of Political Economy, 108(4), 761-777.

Gérin-Jean, P. (2003). Prices of works of art and hierarchy of artistic value on the Italian Market (1400-1700), in Fantoni et al. (2003).

Greif, A., Milgrom, P., \& Weingast, B. (1994). Coordination, commitment and enforcement: The case of the merchant gild. Journal of Political Economy, 102(4), 745-776.

Holmstrom, B. (1979). Moral hazard and observability. Bell Journal of Economics, 10(1), 74-91.

Holmstrom, B., \& Milgrom, P. (1991). Multitask principal-agent analyses: Incentive contracts, asset ownership, and job design. Journal of Law Economics and Organization, 7, 24-52.

Locatelli-Biey, M., \& Zanola, R. (1999). Investment in painting: A short-run price index. Journal of Cultural Economics, 23(3), 209-219.

Malanima, P. (2002). L’Economia Italiana. Dalla crescita medievale alla crescita contemporanea, Bologna: Il Mulino.

Mei, J., \& Moses, M. (2002). Art as investment and the underperformance of masterpieces: Evidence from 1875-2002. American Economic Review, 92(5), 1656-1668.

Melitz, M. (2003). The impact of trade on intra-industry reallocations and aggregate industry productivity. Econometrica, 71(6), 1695-1725.

Montias, J. M. (2002). Art at Auction in 17th Century Amsterdam. Amsterdam: Amsterdam University Press.

Nahm, J. (2010). Price determinants and genre effects in the Korean art market: A partial linea analysis of size effects. Journal of Cultural Economics, 34, 281-297.

Nerlove, M. (1995). Hedonic price functions and the measurement of preferences: The case of Swedish wine consumers. European Economic Review, 39, 1697-1716.

O’Malley, M. (2005). The Business of Art. Contracts and the Commissioning Process in Renaissance Italy. New Haven: Yale University Press.

Palmquist, R. (1984). Estimating the demand for characterisitics of housing. Review of Economics and Statistics, 66, 394-404.

Rengers, M., \& Velthuis, O. (2002). Determinants of prices for contemporary art in Amsterdam art galleries 1992-1998. Journal of Cultural Economics, 26(2), 1-28.

Rosen, S. (1974). Hedonic prices and implicit markets: Product differentiation in pure competition. Journal of Political Economy, 82, 34-55.

Sohm, P. (2010). Venice, Chapter 5 in Spear and Sohm (2010).

Spear, R. \& Sohm, P. (2010). Painting for profit. The economic lives of seventeenth-century Italian Painters, New Haven: Yale University Press. 
Vaubel, R. (2005). The role of competition in the rise of baroque and renaissance music. Journal of Cultural Economics, 29, 277-297.

Witte, A., Sumka, H., \& Erekson, H. (1979). An estimation of a structural hedonic price model of the housing market: An application of Rosen's theory of implicit markets. Econometrica, 47, 1151-1173. 